\title{
Milgram revisited: The role of belief in science
}

\author{
Kyle J. Messick \\ University of South Carolina Beaufort, USA \\ https://orcid.org/0000-0002-0452-0922
}

\begin{abstract}
Belief in science is a term applied to assess the degree to which individuals see science as a positive and moral force. This allegiance to science as a guide for societal progress changes on a cultural level over time, with there being a particularly strong contrast between the widespread distrust of science in modern times and the 'Golden Age of Futurism' that contextualized Milgram's infamous obedience experiments. Milgram's experiments have been critically analyzed for their methods and conclusions, and although many factors have been proposed as possible contributors, society's relationship with science during that era is largely overlooked. This presentation applies belief in science as a likely contributing factor in Milgram's experiments through two primary routes: 1) the experiments took place during a timeframe characterized by a rich embracing of science through major innovations, portrayals in popular media, and celebrity scientists, and 2) the use of belief in science as a prime in a multitude of ways, including legitimizing the experiment with a scientific textbook and by advertising Yale University as the location of the experiments. Belief in science should be considered among contributing factors in discussing Milgram's outcome, as it could contribute to obedience through an appeal to scientific progress, calling further into question Milgram's wartime atrocity applications, and offers an additional reason as to why the obedience experiments would inevitably differ in a modern context.
\end{abstract}




\section{Keywords}

Milgram, obedience, belief in science, authority

\section{Introduction}

In the more than half a century that has followed Milgram's obedience experiments, which began in 1961, seemingly every facet, criticism, and explanation about the validity and reliability of Stanley Milgram's methods and conclusions have been dissected and vivisected, but there is one major influence that continues to get overlooked: belief in science. There was a cultural zeitgeist that embraced science for its future prospects and the way it was revolutionizing daily living throughout the 1950s and 1960s that provided the backdrop for the obedience experiments, and so it is deserving of attention for its role in influencing participants' behavior. The cultural contextualization of science in the 1960s was dissimilar to modern times, so it is a facet that is easily overlooked as we look at the past through the lens of the present. This article discusses the concept of belief in science then applies it to many of the criticisms, replications, and other interpretations of Milgram's obedience experiments.

\section{Milgram's experiments \& conclusions}

Textbooks tend to glaze over the depth and variety in Milgram's obedience experiments. In the opening sentences of his seminal work on the subject, Milgram introduced the concept of obedience as a fundamental structure in society, giving examples as diverse as its role in communal living to the atrocities of the holocaust. Milgram defined obedience as 'a psychological mechanism that links individual action with political purpose' and as 'the dispositional cement that binds men to systems of authority' (Milgram, 1974, pg 1). When Milgram spoke of obedience, he largely focused on the role of obedience in committing heinous 
crimes and atrocities, with the actions of the Third Reich being a prominent example. Milgram sought to move the conversation about obedience from philosophical arguments about its role in social stability towards concrete observations. He first pursued this goal through a simple experiment at Yale University that was intended to increasingly challenge the conscience of each participant through a series of escalating actions. His research question was to determine the moment where participants would refuse to carry out the actions of an authority figure (the experimenter) with the underlining assumption being that the requested actions would conflict with the morality of the participant. It would appear to each participant that two participants were brought in, and one was randomly assigned to the 'learner' condition, and the other to the 'teacher' condition, however, unbeknownst to the participant, they would always be designated as the 'teacher' and the other individual was a confederate that would always play the role of the 'learner.' An experimenter would be present in the room that would explain that the purpose of the experiment was to determine the role of punishment on learning, but this was deception used so that participants would not be keen to discover the true purpose of investigating the influence of authority. The learner was strapped to a seat in an adjacent room with an electrode attached to their wrist. They were to learn a list of word pairs, and if they incorrectly matched a pair of words, the teacher would flip a switch to give the learner electric shocks of increasing voltage. A mock shock generator featuring 30 switches that escalated from 15 volts to 450 volts in 15 -volt increments was used by the teacher to punish the learner for incorrect responses. These switches also had labels from 'slight shock' to 'danger-severe shock' to further emphasize the intensity and risk associated with the shocks. The learner further communicated that the shocks were escalating through a series of vocalizations: at 75 volts, they grunt; at 120 volts, they complain verbally; at 150 volts they demand to be released; and from there their oral protests escalated 
until 285 volts when the confederate screamed agonizingly (Milgram, 1974; pg 4). Excuse the pun, but the results of the experiments were shocking. Milgram found in some variations that as many as two-thirds of participants would shock the learner at the maximum level. This is where the major ethical concerns arise that have been the topic of debate for over half a century: although the confederate was never physically harmed during the experiment, the knowledge and stress of intentionally causing serious harm or death to another being could have serious psychological consequences on the participant, even after being debriefed (Miller, Collins, \& Brief, 1995). Participants should leave an experiment exactly as they came in, but participants could leave Milgram's experiment questioning their own moral compass.

For Milgram, the study illustrated a conflict between conscience and authority that could potentially explain, in addition to the atrocities of Nazi Germany, the "enslavement of millions of black people, the destruction of the American Indian population, the internment of Japanese Americans", and "the use of napalm against civilians in Vietnam" (Milgram, 1974, p. 179). Milgram's conclusions were grim, claiming that his experiments revealed "a fatal flaw natured has designed into us" where man has the capacity to "abandon his humanity... as he merges his unique personality into larger institutional structures" (Milgram, 1974, p. 188). One of the concluding statements from his summary reads "a substantial proportion of people do what they are told to do, irrespective of the content of the act and without limitations of conscience, so long as they perceive that the command comes from a legitimate authority." This was a bold and damning statement, but one that focused solely on authority as the variable that influenced the experimental outcome, however, many scholars have pointed out issues and overlooked facets with the conclusions that Milgram made. 


\section{Causal mechanisms according to Milgram}

Milgram's major assumption was that participants would shock the learner all the way to the maximum level due to commands from the experimenter - the authority figure. Milgram explained this result as coming from a sense of obligation from participants to fulfil their duties as a subject irrespective of their own sense of morality, with the implication being that people can do terrible things when it is ingrained into their jobs, and that few people have the resources and cognitive facility to overcome authority figures when their own morality becomes compromised (Milgram, 1974, p. 5). These resources, claimed Milgram, although not empirically controlled in the obedience experiments, included the inability to overcome being polite, the desire to fulfil the promise of aid to the experimenter, the awkwardness of withdrawal from the experiment, a sort of tunnel-vision towards the task that ignores consequences, and the 'counteranthropomorphism' that occurs when human agency falls to the background when the experiment is described as having its own necessary momentum towards completion (Milgram, 1974, p. 6-9). The last explanation also ties in with systematic dehumanization and devaluation because as participants prioritized the experiment, they noted in post-experiment interviews that they had devalued the learner. What there is a more vigorous explanation towards, as Milgram always noted, was that participants divert responsibility to the experimenter. This diffusion of responsibility would make it feel as though the participant was not responsible for their own actions. Milgram created a number of variations of his initial experiment. In one version, the participant conducted the word-pair test while a second person delivered the shocks, which caused a lessening of responsibility for participants, since the blame was then pushed solely on the person operating the shock machine. Although this moving of responsibility to the authority figure or to an individual responsible solely for activating each shock is one explanation, what 
largely qualifies the experimenter in the eyes of the participant would have been their own views of science, scientists, and scientific institutions, which could limit the generalizability of claims about obedience towards other authority figures. This is important to acknowledge because Milgram drew parallels with the role of obedience in the Third Reich's atrocities and other horrible historical events, which wouldn't have had the same connotation with scientific progress.

\section{The role of belief in science in Milgram's work}

Before jumping into other specific criticisms about Milgram's work, I will first introduce the concept of belief in science, as it is something that can add further contextualization to many of the criticisms discussed. A few critical papers have questioned the role of obedience in Milgram's experiments, and instead have suggested that personal identification with science explained the results (Reicher, Haslam, \& Smith, 2012; Haslam, Reicher, \& Birney, 2014; Haslam \& Reicher, 2012). Indeed, in the 2014 article by Haslam, Reicher, \& Birney, replications of Milgram's classic studies were performed, but it was found that appeals to scientific goals predicted successive levels of shock administration, whereas when the appeals were perceived as orders, there was a negative relationship with shock administration. This argument can be substantiated further through a thorough examination of the relationship between society and science in the 1950s and 1960s. Currently, there is widespread distrust of science and scientific disciplines as a result of widespread misinformation and conspiracy theories that could largely be attributed to the ease of which (mis)information spreads through the world wide web (Scherer et al., 2021; Dias, Pennycook, \& Rand, 2020; Iyengar \& Massey, 2019), but in the time of Milgram, society's relationship and beliefs toward science, which largely saw it as a positive, guiding force, were much more widespread. This article posits that societal belief in science, 
including of scientific-technological progress, is a key factor to be considered when reflecting on Stanley Milgram's obedience experiments. As scientists continue to poke and prod at different explanations for Milgram's findings, it is easy for modern researchers to overlook the role of belief in science due to the modern distrust of science at the societal and cultural level, particularly in Western cultures, partially because there is a perceived contradiction between science and popular religious traditions, despite their perceived compatibility in Eastern cultures (Clobert \& Saroglou, 2015).

In order to contextualize viewpoints about science in Milgram's day more concretely, the concept of belief in science can be applied. Belief in science is the term used to describe individuals who perceive science as a superior guide to reality, using it as a unique and central value. Recently, studies have investigated belief in science as a replacement or surrogate for religious belief, or at least as being functionally similar to religious belief (Farias, Newheiser, Kahane, \& de Toledo, 2013; Aghababaei, Sohrabi, Eskandari, Borjali, Farrokhi, \& Chen, 2016). Belief in science has been shown to bolster moral sensitivity (Yilmaz \& Bahçekapili, 2015) and increase happiness, hope (Aghababaei, 2016), well-being (Aghababaei et al., 2016), and acts as a buffer against stress and existential anxiety (Farias, Newheiser, Kahane, \& de Toledo, 2013), similar to how religious beliefs can act as a buffer against death anxiety (Jackson, Jong, Bluemke, Poulter, Morgenroth, \& Halberstadt, 2018). Similar has been evidenced by other overlapping constructs too, such as belief in progress (Rutjens, van der Pligt, \& van Harrevald, 2009). A belief in scientific-technological progress, a concept with much overlap with belief in science, has been associated with higher life satisfaction (Stavrova, Ehlebracht, \& Fetchenhauer, 2016). Belief in progress can provide a source of meaning, act as a buffer against mortality, and give individuals a sense of control (Rutjens, van Harreveld, \& van der Pligt, 2010; Rutjens, van 
der Pligt, \& van Harreveld, 2009). It alleviates the experience of low levels of control through a belief that, overall, humanity is progressing (Rutjens, van Harreveld, van der Pligt, van Elk, \& Pyszczynski, 2016). The functions of belief in science reinforce it as a guiding value, and if it is the case that Milgram's participants' had a strong belief in science, then that belief would have greatly influenced the relationship between Milgram's participants and their behavior in his obedience experiments. Supporting evidence can be gathered from the timeframe leading up to the obedience experiments that belief in science was reasonably high on a cultural level, especially as a contrast to modern times.

The decade leading up to Milgram's experiments saw tremendous scientific innovation, including the first successful organ transplant, the creation of the polio vaccine, the introduction of the color television, the invention of the birth control pill, the production of the first commercially available computer, the revolution of travel through the use of jet aircraft, and the founding of NASA. It was an era where the direct influence of science on daily life was immediately observable and quantifiable, even by laypeople, as it drastically changed how people lived. Peter Salk, son of polio vaccine inventor Jonas Salk, asserted the role of belief in science in an interview reflecting on the polio vaccine, "Back in the 1950s, people really looked to science and medicine as something that would make their lives better" (Rothenberg Gritz, 2014). The 1950s also embraced science as a guiding force of innovation through popular media, including the science fiction radio shows Dimension X, X Minus One, Planet Man, Space Patrol, Exploring Tomorrow, and Tom Corbett Space Cadet, the latter of which became a television show. The 1950s also hosted a number of science fiction comic books, including Space Adventures, Captain Science, Other Worlds, Strange Worlds, and Weird Science.

The timeframe from 1958 and 1963 has often been referred to as 'the Golden Age of 
American Futurism,' which is used to describe a time when the American public was fascinated with the future possibilities of technology, science, and industry, and so it is important to contextualize what it means that Milgram's experiments took place in the middle of that 'golden age.' The American public had a loving and positive relationship with science, which had also extended to popular television shows, including the animated sitcom The Jetsons that ran from 1962 to 1963 . The show documented the life of a family in a far advanced technological future with robots, holograms, and whimsical inventions. The Sunday newspaper also had a comic strip that ran during this timeframe called Closer Than We Think, which included such futuristic ideas as solar-powered cars, robots, jetpacks, meal pills, and flying cars. In addition, science also had a place in celebrity in the years leading up to Milgram, as Albert Einstein was a famous icon of American science. Einstein passed away only six years prior to Milgram's first obedience experiment. Einstein's influence and fame was such that he was routinely asked his opinions on matters outside of science, which provides yet another example of the fond relationship and trust that Americans had at the time not only for science, but also scientists. Although Milgram certainly didn't approach the level of fame of Einstein, any positive stereotypes about scientists held by society would have likely applied to Milgram or any scientist conducting experiments during that era. Going back a bit before Einstein, Nikola Tesla was an inventor and a futurist that would be visited in his lab by celebrities and wealthy patrons to see his achievements, illustrating that even the famous were intrigued by science in the decades leading up to Milgram.

This zeitgeist towards science and futurism is encapsulated well by the speech given by President John F. Kennedy about a year after Milgram began his obedience experiments. On September $12^{\text {th }}, 1962$, Kennedy gave a speech in front of a crowd in Houston, Texas that invoked a spirit of scientific dominance as he encouraged that America's resources be used to fund space 
exploration, and in particular, cause people to land on the moon. This was realized a mere seven years later when the Apollo 11 mission was successful. The $\$ 40$ billion that was needed to accomplish this feat was a tremendous amount of money at the time, and it is worth noting that the incorporation of science into media didn't entirely translate into funding for such ambitious ideas, as there was a lot of pushback from the public towards funding the moon landing, although that somewhat alleviated in the months prior to the moon landing (Launius, 2003).

Innovations and the embracing of science in media set the stage for Milgram's participants to be influenced by a societal belief in science that saw it is a guiding, positive force towards the future. This baseline belief in science is easily neglected as a result of the current global landscape, with anti-intellectual and anti-science movements being especially vocal in popular media, politics, and through the viral nature of internet information. To clarify, that doesn't mean that scepticism didn't exist in regards to science in the 1950s and 1960s, but rather, the argument being made is that society had an overall fonder view of science in the 1960s than in recent years, enough so that it would have had predictive quality in regards to Milgram's experimental outcome, as demonstrated by Haslam, Reicher, \& Birney (2014). In current times, there is a 'crisis of faith' in science as a result of biased agendas, conspiracy thinking, and perceptions about the morality of science (Rutjens et al., 2018), but the cultural context was different over half a century ago. This stark difference between attitudes towards science, and thus, also, a belief in science, means that the conditions under which Milgram's obedience experiments would be difficult to replicate in a modern replication, and would limit the generalizability of Milgram's claims. The higher degree of belief in science likely translated into higher levels of trust in the experimenter, obedience to the experimenter, and faith that completing the experiment was for the greater good. 


\section{Contextualizing criticisms, alternative explanations, \& replications}

Replicating Milgram's experiments is one of the biggest cruxes in validating Milgram's conclusions, due to modern ethical guidelines preventing precise replication. The changes that are necessary to conduct any variation of Milgram's obedience experiments in modern times fundamentally alter the experiments from Milgram's design (Burger, 2009). Despite this difficulty, people have still conducted many different variations in order to test the claim that individuals will obey authority figures if it diffuses responsibility for their own actions. One variation conducted the experiment in a digital environment, which still caused participants to react psychologically as if the experiments were real. Participants became stressed as they permitted electric shocks to a virtual learner. The virtual experiment showed similar results to what Milgram found, but with less intensity (Slater et al., 2006). One of the key differences between the virtual experiment and Milgram's experiments was that the virtual learner did not object in as intensely negative a fashion that was demonstrated by the confederates in Milgram's studies. For example, there was no protestation to shocks related to a heart condition.

Researchers have also questioned the generalizability of Milgram's findings due to variables that Milgram didn't take into consideration in his findings. For example, Milgram only used male teachers, learners, and authority figures, whereas some replications have explored the role of gender (Doliński et al., 2017; Burger, 2009). Others have explained Milgram's findings through different mechanisms, such as through identification-based followship instead of through ceding responsibility to an authority figure (Reicher, Haslam, \& Smith, 2012). In this theory, it is through identification with either the experimenter or the scientific community that he represented that would've caused participants to shock the learner in the experiment, and this explanation is given further traction when looking at societal belief in science during the era. 
There are other facets of the experiment that don't generalize well to real life. For example, the authority figure was always present and always played a motivational role, which adds an additional level of pressure on the participant that doesn't necessarily parallel real life, since not every task in life is always carried out under direct observation or with continual, consistent encouragement. Milgram's experimenter also accepted responsibility for the actions of the participant, which also doesn't often parallel real life.

There are many additional factors that could influence Milgram's results that need consideration, including enduring beliefs, personality (Blass, 1991; 1999; Zeigler-Hill et al., 2013), social identity perspectives that consider moral obligations, if the requests to shock are framed as orders (Reicher \& Haslam, 2011), many variables pertaining to the experimenter (Haslam, Loughnan, \& Perry, 2014), and embodiment (Neyret et al., 2020), among others. Worse yet, some scholars have claimed that Milgram misrepresented aspects of his experiments and selectively reported results (Brannigan, Nicholson, \& Cherry, 2015; Nicholson, 2011).

Another area of debate is perceived power and influence of the experimenter. Milgram stated that surely the perceived power of the experimenter was less than a General in the armed forces (Milgram, 1974, p. 4), however, that might not necessarily be the case. The time frame in which Milgram's experiments took place was when society generally had a positive outlook towards science, scientists, and technology, whereas they were more sceptical of federal authoritative figures following the second World War. In this way, one could even make an argument that as a result of society's love affair with science, illustrated by the embracing of prominent scientists as celebrities, participants might have been more likely to obey a scientist over a General depending on the individual, thus further delegitimizing Milgram's claims. This is substantiated by that participants do not complete successive shocks when they are framed as 
orders, rather, they continue to shock only when there is an appeal to scientific progress (Haslam, Reicher, \& Birney, 2014). This shows directly that claims about authority and obedience are oversimplified, as there is a huge and potentially dominant role being played by participants' belief in science. Milgram described his experiment as having 'modest' circumstances compared to those found in war (Milgram, 1975, p. 4), but due to the zeitgeist towards seeing science through a positive outlook in the 1960s, participants might not have shared Milgram's humble perspective about his scientific workings. Science was changing daily life for the better, as was illustrated in fiction and in the trend towards futurism. It is also worth noting that the experimenter wore a gray technician's coat (Milgran, 1974, p. 16), which is noteworthy because of the effect and connotations of lab coats in experimental settings and because they further prime belief in science (Jones et al., 2019; Ellis, 2010).

The role of belief in science can also give context to how Milgram recruited participants. After initial studies with students, Milgram recruited participants through an advertisement in the local newspaper because Milgram felt that recruiting undergraduate students could compromise the true purpose of his experiment. This is another point where baseline belief in science could have an influence on Milgram's experiments, as people with a more positive view of science, even in a timeframe that was largely optimistic about the prospects of scientific progress, would have been more likely to enrol in a scientific experiment. The enrolment process was particularly involved, too, as participants had to cut out and fill out an ad found in the newspaper, and then mail it directly to 'Professor Stanley Milgram, Department of Psychology, Yale University' mandating a direct interaction between the potential participant and a scientist at a prestigious university to even be considered for participation. This recruitment method was not satisfactory in getting the number of participants desired, so Milgram supplemented this with direct mail 
solicitation (Milgram, 1974, p. 16). This is another potential issue for Milgram's experiment: the recruitment method itself could have selectively pulled participants that were already more obedient as a result of direct solicitation. $12 \%$ of those mailed responded to the invitation, meaning that these individuals could have already had a disproportionately high pro-science mindset in a pro-science time, and might have already been more enthusiastic about obeying a scientist even prior to the obedience experiment, evidenced by their responding to an email summons for participation.

The obedience experiments are often taught in classrooms without much emphasis on how participants were primed prior to the experiment. The experimenter held a book on the teaching-learning process and explained to participants that the book included a theory that people learn correctly whenever they get punished for making a mistake (Milgram, 1974, p. 18). This is an important distinction because when drawing parallels between atrocities following commands in real life, there is not always an explanation provided, and certainly not one supposedly derived from science. Before Milgram's experiment commenced, it was established for the participant that science has found that the method in the experiment is genuine, legitimate, and scientifically-founded. A specific example was provided too, which was how spanking was used to teach children right from wrong, which was a widely acceptable practice at the time. This initial action primes the legitimacy of science and of punishment before the experiment began. There were then three levels of belief in science in place that directly impacted Milgram's experiments: 1) the high societal baseline, 2) the higher level associated with enrolment in the experiment, and 3) the higher level primed and validated by establishing the legitimacy of the science at the beginning of the experiment. There is yet one more level of belief in science that is primed, which is through the location of the experiments themselves. 


\section{Yale University \& belief in science}

Between 1925 and 1940, numerous philanthropic organizations including those run by the Rockefellers, had donated around seven million dollars to Yale University to expand their pursuit of the behavioural sciences. The goal of these donations included a desire to 'improve mankind', which is consistent with belief in science and the popularity of futurism. These large donations were documented well through media outlets, and so it is entirely probable that twenty years after the culmination of these funds that participants would still have associated Yale with moral, scientific progress that served the greater good. Milgram recruited laypeople through newspapers instead of using university undergraduates, and the advertisements included descriptions of it being a "scientific study" and clearly noted that its location was Yale University. To enrol in the experiment, participants had to mail "Stanley Milgram, Department of Psychology, Yale University" (Milgram, 1974, p. 15). This use of using Yale University in advertisements targeting laypeople would prime science associations with Yale University.

Being aware of the pro-scientific zeitgeist prevalent during the time of Milgram's experiments that included futurism and was represented by places like Yale University, or at least that science and scientists were largely viewed in a positive light, would have primed participants during experiments at one of the nation's leading scientific enterprises. Stanley Milgram was a representative of Yale University, and so he represented the over two-hundred year tradition of rich academic and scientific history associated with Yale. Priming participants with Yale University likely bolstered belief in science, so it should be an additional factor to consider when interpreting Milgram's findings through a modern lens, or at least as an additional mediating factor. 


\section{Applying belief in science in future analyses of Milgram's experiments}

This article has made a case for Milgram's obedience experiments being largely influenced by the relationship between society and science during that era, which has been described here using the term belief in science and applying it into a broad cultural context. Milgram's experiments took place in a timeframe characterized by an embracing of futurism, the directly observable presence of science in revolutionizing daily life, prominent scientists maintaining celebrity status, and science being widespread in popular media. All of this would have contributed to Milgram using belief in science as a direct and indirect prime, including through preemptively validating the experiments to participants by using a scientific book, through having an experimenter wear a lab coat, by priming participants with Yale University, through direct recruitment solicitation by a scientist (increasing the likelihood that participants would be obedient to scientists in particular), and through recruiting participants that already might have a higher level of belief in science. All of these facets limit the extent to which Milgram's generalizations about obedience to all authority figures can be validated, and it is hoped that future analyses of Milgram's famous experiments contextualize the results with other contextual factors in mind, including belief in science.

\section{References}

Aghababaei, N., Sohrabi, F., Eskandari, H., Borjali, A., Farrokhi, N., \& Chen, Z. J. (2016).

Predicting subjective well-being by religious and scientific attitudes with hope, purpose in life, and death anxiety as mediators. Personality and Individual Differences, 90, 93-98.

Aghababaei, N. (2016). Scientific faith and positive psychological functioning. Mental Health, Religion \& Culture, 19(7), 734-741. 
Blass, T. (1991). Understanding behavior in the Milgram obedience experiment: The role of personality, situations, and their interactions. Journal of personality and social psychology, 60(3), 398-413.

Blass, T. (1999). The Milgram Paradigm After 35 Years: Some Things We Now Know About Obedience to Authority 1. Journal of applied social psychology, 29(5), 955-978.

Brannigan, A., Nicholson, I., \& Cherry, F. (2015). Introduction to the special issue: Unplugging the Milgram machine. Theory \& Psychology, 25(5), 551-563.

Burger, J. M. (2009). Replicating Milgram: Would people still obey today?. American Psychologist, 64(1), 1-11.

Clobert, M., \& Saroglou, V. (2015). Religion, paranormal beliefs, and distrust in science: Comparing East versus West. Archive for the Psychology of Religion, 37(2), 185-199.

Dias, N., Pennycook, G., \& Rand, D. G. (2020). Emphasizing publishers does not effectively reduce susceptibility to misinformation on social media. Harvard Kennedy School Misinformation Review, 1(1).

Doliński, D., Grzyb, T., Folwarczny, M., Grzybała, P., Krzyszycha, K., Martynowska, K., \& Trojanowski, J. (2017). Would you deliver an electric shock in 2015? Obedience in the experimental paradigm developed by Stanley Milgram in the 50 years following the original studies. Social psychological and personality science, 8(8), 927-933.

Ellis, O. (2010). The return of the white coat?. BMJ, 341:c4725. 
Farias, M., Newheiser, A. K., Kahane, G., \& de Toledo, Z. (2013). Scientific faith: Belief in science increases in the face of stress and existential anxiety. Journal of experimental social psychology, 49(6), 1210-1213.

Haslam, S. A., Reicher, S. D., \& Birney, M. E. (2014). Nothing by mere authority: Evidence that in an experimental analogue of the Milgram paradigm participants are motivated not by orders but by appeals to science. Journal of Social Issues, 70(3), 473-488.

Haslam, S. A., \& Reicher, S. D. (2012). Contesting the "nature" of conformity: What Milgram and Zimbardo's studies really show. PLoS Biology, 10(11).

Haslam, N., Loughnan, S., \& Perry, G. (2014). Meta-Milgram: An empirical synthesis of the obedience experiments. PloS one, 9(4), e93927.

Iyengar, S., \& Massey, D. S. (2019). Scientific communication in a post-truth society. Proceedings of the National Academy of Sciences, 116(16), 7656-7661.

Jackson, J. C., Jong, J., Bluemke, M., Poulter, P., Morgenroth, L., \& Halberstadt, J. (2018). Testing the causal relationship between religious belief and death anxiety. Religion, Brain \& Behaviour, 8(1), 57-68.

Jones, M. G., Lee, T., Chesnutt, K., Carrier, S., Ennes, M., Cayton, E., ... \& Huff, P. (2019). Enclothed cognition: putting lab coats to the test. International Journal of Science Education, 41(14), 1962-1976.

Launius, R. D. (2003). Public opinion polls and perceptions of US human spaceflight. Space Policy, 19(3), 163-175.

Milgram, S. (1974) Obedience to Authority. Harper \& Row. 
Miller, A. G., Collins, B. E., \& Brief, D. E. (1995). Perspectives on obedience to authority: The legacy of the Milgram experiments. Journal of Social Issues, 51(3), 1-19.

Neyret, S., Navarro, X., Beacco, A., Oliva, R., Bourdin, P., Valenzuela, J., ... \& Slater, M. (2020). An embodied perspective as a victim of sexual harassment in virtual reality reduces action conformity in a later milgram obedience scenario. Scientific reports, $10(1)$, $1-18$.

Nicholson, I. (2011). Torture at Yale": Experimental subjects, laboratory torment and the "rehabilitation” of Milgram's “Obedience to Authority. Theory \& Psychology, 21(6), 737-761.

Reicher, S. D., Haslam, S. A., \& Smith, J. R. (2012). Working toward the experimenter: Reconceptualizing obedience within the Milgram paradigm as identification-based followership. Perspectives on psychological science, 7(4), 315-324.

Reicher, S., \& Haslam, S. A. (2011). After shock? Towards a social identity explanation of the Milgram ‘obedience’studies. British Journal of Social Psychology, 50(1), 163-169.

Rottenberg Gritz, J. (October 28 2014). The anti-vaccine movement is forgetting the Polio epidemic. The Atlantic. Retrieved from https://www.theatlantic.com/health/archive/2014/10/the-anti-vaccine-movement-isforgetting-the-polio-epidemic/381986/

Rutjens, Bastiaan T. and Heine, Steven J. and Sutton, Robbie M. and van Harreveld, Frenk (2018) Attitudes Towards Science. Advances in Experimental Social Psychology, 57, 125-165. ISSN 0065-2601. 
Rutjens, B. T., van Harreveld, F., van der Pligt, J., van Elk, M., \& Pyszczynski, T. (2016). A march to a better world? Religiosity and the existential function of belief in social-moral progress. The International Journal for the Psychology of Religion, 26(1), 1-18.

Rutjens, B. T., van der Pligt, J., \& van Harreveld, F. (2009). Things will get better: The anxietybuffering qualities of progressive hope. Personality and Social Psychology Bulletin, 35(5), 535-543.

Rutjens, B. T., van Harreveld, F., \& van der Pligt, J. (2010). Yes we can: Belief in progress as compensatory control. Social Psychological and Personality Science, 1(3), 242-252. doi:10.1177/1948550610361782

Scherer, L. D., McPhetres, J., Pennycook, G., Kempe, A., Allen, L. A., Knoepke, C. E., ... \& Matlock, D. D. (2021). Who is susceptible to online health misinformation? A test of four psychosocial hypotheses. Health Psychology.

Slater, M., Antley, A., Davison, A., Swapp, D., Guger, C., Barker, C., ... \& Sanchez-Vives, M. V. (2006). A virtual reprise of the Stanley Milgram obedience experiments. PloS one, $1(1)$.

Stavrova, O., Ehlebracht, D., \& Fetchenhauer, D. (2016). Belief in scientific-technological progress and life satisfaction: The role of personal control. Personality and Individual Differences, 96, 227-236.

Yilmaz, O., \& Bahçekapili, H. G. (2015). When science replaces religion: Science as a secular authority bolsters moral sensitivity. PloS One, 10(9), e0137499. 
Zeigler-Hill, V., Southard, A. C., Archer, L. M., \& Donohoe, P. L. (2013). Neuroticism and negative affect influence the reluctance to engage in destructive obedience in the Milgram paradigm. The Journal of Social Psychology, 153(2), 161-174. 